\title{
Appendiceal schwannoma: a rare cause of perforated appendicitis
}

\author{
Thomas Hendriks, ${ }^{1}$ Helen Ballal, ${ }^{1}$ Dugald Dalziel McCallum ${ }^{2}$
}

${ }^{1}$ Fiona Stanley Hospital, Murdoch, Western Australia, Australia

${ }^{2}$ PathWest, Royal Perth Hospital, Perth, Western Australia, Australia

\section{Correspondence to} Dr Thomas Hendriks, thomas.hendriks@health.wa. gov.au

Accepted 22 June 2018

\section{DESCRIPTION}

An 82-year-old woman presented to the emergency department with an acute abdomen. CT imaging revealed a proximal appendiceal mass with distal appendicitis. She underwent a laparoscopic appendicectomy with partial caecectomy and subsequent histopathology confirmed an appendiceal schwannoma.

The woman presented with a 1-day history of acute abdominal pain localised to the lower quadrants, worse on mobilisation, loss of appetite and fever. She denied any previous abdominal pain, nausea or vomiting, bowel or bladder symptoms. There was no history of weight loss, generalised fatigue or other symptoms of chronic anaemia. She had been well in the preceding weeks. Her medical history was significant for a cerebrovascular accident, hypertension and hypercholesterolaemia. She had never had previous abdominal surgery.

On examination the patient had a temperature of $37.7^{\circ} \mathrm{C}$. There were no signs of haemodynamic instability. Her abdomen was rigid with severe tenderness on palpation, worse in the right lower quadrant. Generalised percussion tenderness was present.

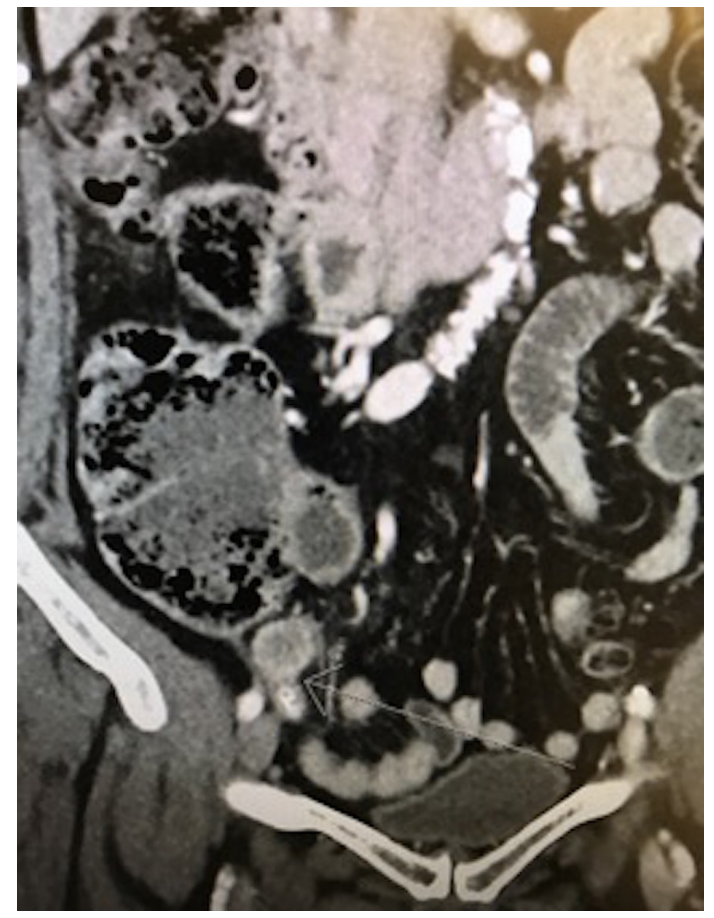

Figure 1 Coronal CT demonstrating the proximal appendiceal mass.

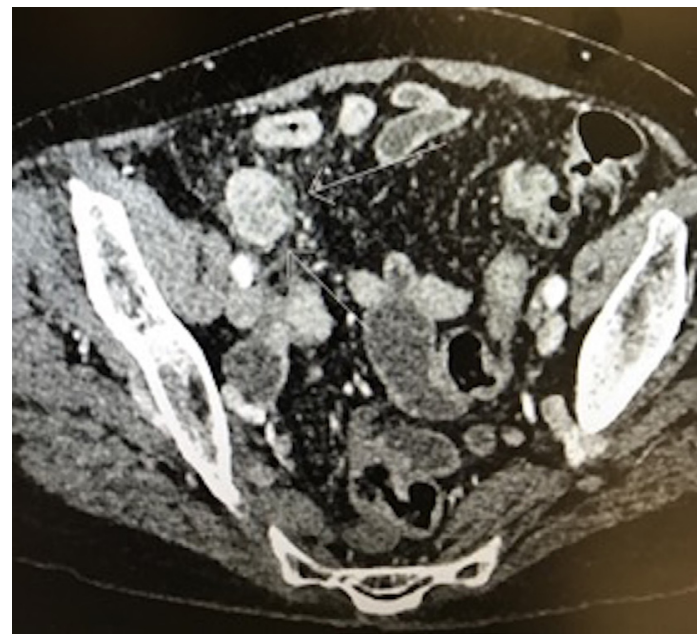

Figure 2 Axial CT demonstrating the proximal appendiceal mass and associated inflammatory stranding.

Her blood results showed elevated inflammatory markers (white cell count $12.4 \times 10^{9} / \mathrm{L}$ and C-reactive protein $49 \mathrm{mg} / \mathrm{L}$ ). A CT scan revealed a $23 \mathrm{~mm}$ proximal appendiceal mass with associated distal appendiceal dilatation and surrounding inflammation (see figures 1 and 2).

The patient underwent an urgent laparoscopic appendicectomy, partial caecectomy and washout. A partial caecectomy was performed given the intraoperative appearances of a thickened appendix base and radiological evidence of a proximal mass in order to ensure a tumour-free margin. The appendix was perforated with copious amounts of pus; however, the caecum appeared normal. Her recovery was uneventful and she was discharged with outpatient follow-up. Histopathology demonstrated characteristic features of a schwannoma including spindle cell morphology, nuclear

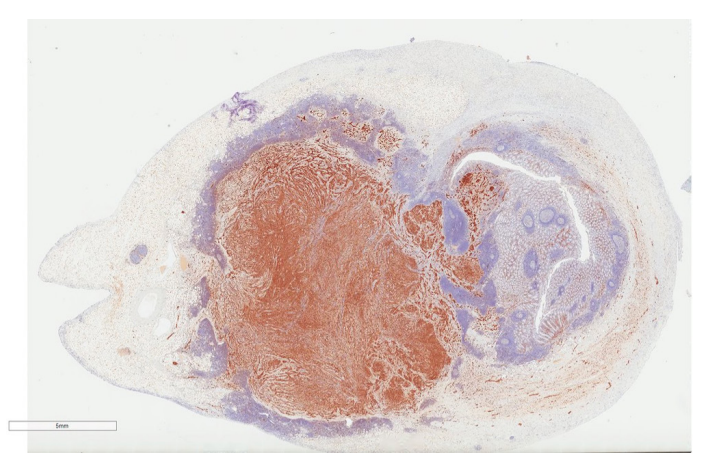

Figure 3 Appendiceal schwannoma identified with immunohistochemistry S100 staining. 


\section{Learning points}

- Most cases of appendicitis either have no definite antecedents or are associated with obstructive faecoliths, lymphoid hyperplasia or diverticulae.

- Appendiceal tumours mimic acute appendicitis by obstruction or perforation but more often present as incidental radiological findings.

- Appendiceal tumours not infrequently associated with acute appendicitis include appendiceal mucinous neoplasms, mostly low grade or neuroendocrine tumours, also mostly of low grade type.

- Schwannomas, the most common benign peripheral nerve sheath tumour, are unusual in the gastrointestinal tract, rare in the appendix and as a cause of acute appendicitis rarer still.

- Pathologically, their differential diagnosis in this unusual location would include a gastrointestinal stroma tumour and the inclusion of $\mathrm{S} 100$ to the immunohistochemistry panel and careful examination for Antoni A and B areas, nuclear palisading, Verocay bodies and typical vascular pattern of the former would avoid diagnostic pitfalls.

- This case highlights a relatively common tumour, in an unusual location, presenting as acute appendicitis.

- Even though it is a benign and completely excised tumour, it serves as an important reminder to consider the various aetiologies of acute appendicitis preoperatively and intraoperatively as this may determine surgical technique and follow-up.

palisading, Verocay bodies and positive S-100 (see figure 3) and negative CD34 and CD117 staining. ${ }^{1-3}$ Although the tumour bulged into the mesoappendix, all margins were clear.

Contributors The report was written by TH with assistance from HB and DDM. HB was the overall supervisor of the report. The histopathology image was provided by DDM. All authors read and approved the final case report.

Funding The authors have not declared a specific grant for this research from any funding agency in the public, commercial or not-for-profit sectors.

Competing interests None declared.
Patient consent Obtained.

Provenance and peer review Not commissioned; externally peer reviewed.

\section{REFERENCES}

1 Skovronsky DM, Oberholtzer JC. Pathologic classification of peripheral nerve tumors. Neurosurg Clin NAm 2004;15:157-66.

2 Levy AD, Quiles AM, Miettinen M, et al. Gastrointestinal schwannomas: CT features with clinicopathologic correlation. AJR Am J Roentgenol 2005;184:797-802.

3 Brunicardi C. The appendix. In: Brunicardi FC, Andersen DK, Billiar TR, et al. eds. Schwartz's principles of surgery. 8th edn. New York, NY: McGraw-Hill, 2005:1119-37.

Copyright 2018 BMJ Publishing Group. All rights reserved. For permission to reuse any of this content visit

http://group.bmj.com/group/rights-licensing/permissions.

BMJ Case Report Fellows may re-use this article for personal use and teaching without any further permission.

Become a Fellow of BMJ Case Reports today and you can:

- Submit as many cases as you like

- Enjoy fast sympathetic peer review and rapid publication of accepted articles

- Access all the published articles

- Re-use any of the published material for personal use and teaching without further permission

For information on Institutional Fellowships contact consortiasales@bmjgroup.com

Visit casereports.bmj.com for more articles like this and to become a Fellow 